\title{
A SEGREGAÇÃO NA DIALÉTICA DA ALTERIDADE
}

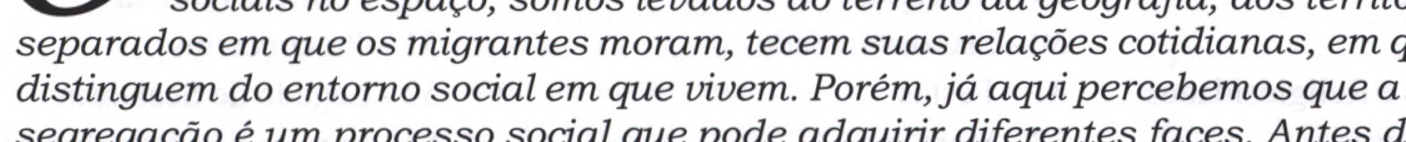
segregação é um processo social que pode adquirir diferentes faces. Antes de tudo, falar de segregação é também falar da operação de segregar, da ação muitas vezes concertada socialmente, pela qual grupos dominantes separam outros, visando distingui-los para melhor controlá-los. Na ação da segregação, o "outro" também é freqüentemente estigmatizado, visto como uma ameaça em potencial, e por isso mantido à margem.

Mas, também há uma ação de segregação dos próprios migrantes, como uma espécie de corporativismo, em que buscam assegurar e preservar as oportunidades conquistadas na sociedade de recepção. Seria então uma "auto-segregação", aquela da defesa do seu próprio território, no bairro em que se mora ou num determinado local de trabalho, filtrando influências possivelmente hostis do entorno em que o grupo se situa? De muitas formas, os migrantes buscam se "separar", para melhor demarcar sua identidade pela afirmação de sua alteridade, para apresentá-la de forma positiva aos "outros" da sociedade em que se inserem, e valorizar-se socialmente. Os migrantes criam e mantêm, por meio de diversas estratégias, inclusive instituições sociais estabelecidas como sindicatos e associações, o seu território de inserção social, a sua "reserva de mercado" de trabalho ou moradia.

Enfim, tratar da segregação significa entrar nos meandros da dialética da alteridade, em que estão envolvidos os migrantes na busca de sua inserção social. Significa também colocar em questão as reações sociais e politicas, no cotidiano e na esfera pública, da gente comum e das instituições sociais, pelas quais os migrantes são segregados e colocados à margem da sociedade. A dialética da alteridade do migrante revela inúmeros aspectos da única dialética de toda a sociedade em movimento, dos que chegam e dos que estão estabelecidos, estando todos obrigados a se recomporem em meio às transformações sociais, das quais a migração é a face mais visivel. Porém, sobretudo, esse número da Travessia traz também à tona que os migrantes não são sujeitos passivos, mas que, com todas as suas contradições, buscam suas próprias formas de se recomporem e se afirmarem socialmente.

Sidnei Marco Dornelas 